\title{
Osteoblastoma of the lumbar spine in an adolescent: A case report and review of literature
}

\author{
Bhushan Sagade ${ }^{1}$, Sarang Rokade ${ }^{1}$, Arjun Dhawale ${ }^{1}$, Abhay Nene ${ }^{1}$
}

\section{Abstract}

Introduction: Osteoblastomas are primary bone tumors representing $1 \%$ of all bone tumors and $10 \%$ of all spinal osseous neoplasms with a predilection for posterior elements.

Case report: A 13-year-old boy with insidious backache for six months presented with progressive radiating paraesthesia and claudication, restricted lumbar motion and positive straight leg test bilaterally with weakness of left ankle dorsiflexion. Radiograph showed an subtle expansile lytic lesion in the L3 posterior elements. CT and MRI revealed a space-occupying lesion of the L3 vertebra lamina, involving the left pedicle causing severe spinal canal stenosis. Excision of the posterior elements of the L3 vertebra including the facet and left pedicle and short segment fixation from L2-L4 using autogenous rib was done.

At two years postoperatively, he was asymptomatic, neurologically normal, showing radiographic evidence of union with no recurrence.

Conclusion: Autogenous structural rib can be used for posterolateral fusion after osteoblastoma excision with potential instability. Keywords: Osteoblastoma, back pain, rib graft, postero-lateral fusion, en-bloc resection.

\section{Introduction}

Osteoid osteoma was first described by Jaffe in 1935 [1], osteoblastomas were described by Jaffe and Lichenstein in 1956 independently [2]. They are benign bone tumours constituting about $11 \%$ of all primary bone tumours [1-3]. The condition is more frequent in males, (male to female ratio of 2:1) and occurs during the second decade of life [1-3]. The most common location for these lesions is the spine with a preponderance for posterior elements of the spine constituting $30-40 \%$ of all the cases $[1,3,4]$. Two types of osteoblastoma have been described in the literature; conventional osteoblastomas and aggressive osteoblastomas, the latter being characterised by high alkaline

${ }^{1}$ Department of Paediatric Orthopaedics, Bai Jerbai Wadia Hospital for Children, Parel, Mumbai 400012

Address of Correspondence

Dr. Dhawale Arjun A,

Department of Paediatric Orthopaedics, Bai Jerbai Wadia

Hospital for Children, Parel, Mumbai 400012

E-mail: arjundhawale@hotmail.com phosphatase levels and size of more than

$1.5 \mathrm{cms}$ with paravertebral or epidural extension and lytic changes on radiographs [4].

Treatment of osteoblastomas of the spine involves en bloc excision of the lesion in Enneking stage 3 lesions and intralesional curettage in Enneking stage 2 lesions $[5,6]$. Radiotherapy is considered as an adjuvant or an alternative to surgical excision if excision demands unacceptable functional sacrifice or in non-accessible locations [7]. Recurrence can occur if excision is inadequate. Overall recurrence rates reported for osteoblastomas has been around $10-15 \%$ [2]. Recurrences are typically seen 5-10 years after index procedure [4].

We describe a case of osteoblastoma of posterior elements of $L 3$ vertebra in a 13year-old boy treated with en bloc excision and posterolateral fusion using rib autograft.

\section{Case report}

A 13-year-old boy presented to clinic with complaints of low back pain of six months duration which was insidious in onset, gradually worsening with time. Pain was present during rest, it radiated to both lower limbs associated with parasthesia, and claudication symptoms with walking, with relief on lying down with the hips and knees flexed. There was no history of trauma, heavy weightlifting, no unaccustomed activity, no history of fever, weight loss, loss of appetite, tuberculosis, no morning stiffness, or small joint pains. Past medical history was unremarkable. On examination there was restriction of movements of the lumbar spine and focal tenderness over the lumbar region. Power of ankle dorsiflexion on the left side was grade 3 . Ankle jerk on the left side was diminished. Rest of the neurological examination was unremarkable.

Radiograph showed a lytic lesion in posterior elements of L3. MRI revealed a space occupying lesion in the posterior

Submitted Date: 4-Sep 2021, Review Date: 12-Nov-2021, Accepted Date: 12-Nov-2021 \& Published Date 31-Dec-2021

Journal of Clinical Orthopaedics | Available on www.jcorth.com | DOI:10.13107/jcorth.2021.v06i02.449 This is an Open Access article distributed under the terms of the Creative Commons Attribution NonCommercial-Share Alike 4.0 License (http://creativecommons.org/licenses/by-nc-sa/4.0) which allows others to remix, tweak, and build upon the work non-commercially as long as appropriate credit is given and the new creation are licensed under the identical terms. 


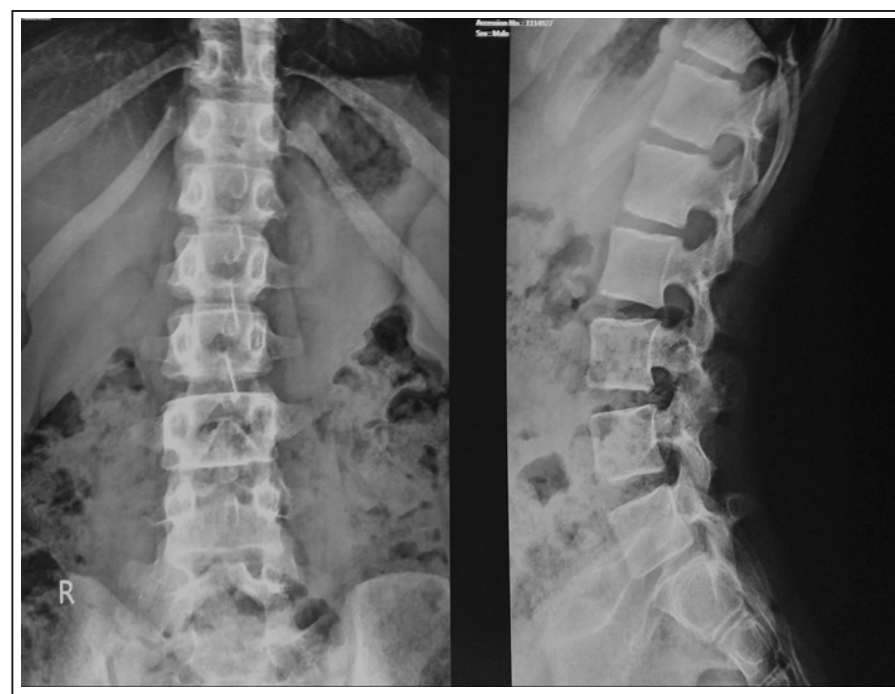

Figure 1: Plain radiograph of the lumbosacral spine Antero-posterior and Lateral view. The Antero-posterior view shows widening and irregularity of the left pedicle of L3. There is irregularity and widening visible in the posterior elements of $\mathrm{L} 3$ on the Lateral radiograph
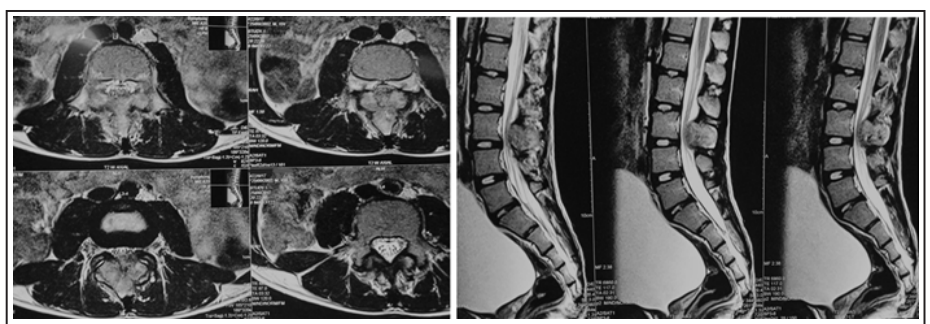

Figure 2: Preoperative MRI of the Lumbosacral spine sagittal and axial sections showing isointense lesion involving the lamina and pedicles of the L3 vertebra with expansion of the bony posterior elements causing severe compression of the left sided L3 nerve root

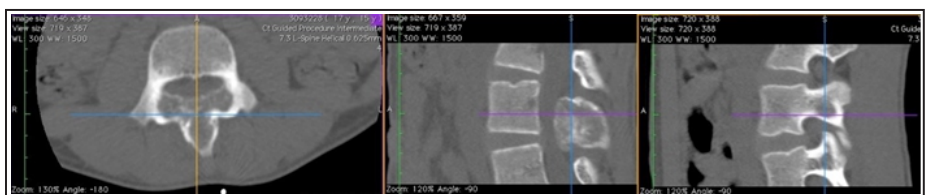

Figure 3: Preoperative axial and sagittal sections of CT scan of the Lumbar spine showing an expansile bony lesion with lytic and sclerotic components arising from the spinous process and extending into the left pedicle of $L 3$ vertebra causing severe stenosis of the neural canal elements of L3 involving the left pedicle and causing severe spinal canal stenosis. CT revealed a heterogeneous expansile bony lesion with lytic and sclerotic component arising from the spinous process of the L3 vertebra extending into the left pedicle (Figure 1-3). A PET-CT scan showed the solitary lumbar lesion with no other lesion elsewhere. Alkaline phosphatase level was 224 IU/L(Normal-38-94IU/L).

After pre-operative work-up, consent and general anaesthesia, patient was positioned prone; exposure of L2-L4 levels was done after level confirmation. En bloc excision of the L3 lamina including the facet joint and left pedicle was done as these were involved. Posterior stabilisation with pedicle screws at L 2 and L4 was done. Posterolateral fusion was performed to prevent iatrogenic instability and autogenous rib graft (left 10th rib) was harvested for fusion (Figure 4). The estimated blood loss was $200 \mathrm{ml}$. Closure was performed and the patient was extubated, the post-operative period was uneventful.

Histopathological examination of the resected specimen confirmed the lesion to be osteoblastoma (Figure 5).

Patient followed up every six months and at two years' post-operatively has had no symptoms or radiological evidence of recurrence of the disease or implant loosening (Figure 6, 7,8).

\section{Discussion}

Clinical presentation: Osteoid osteomas and osteoblastomas of the spine are uncommon tumours which may present with atypical symptoms and normal radiological findings in the initial course of the disease and thus may lead to delays in diagnosis [2]. It may present as persistent, dull back pain. Other presentations may include a painful scoliosis. Scoliosis is usually convex

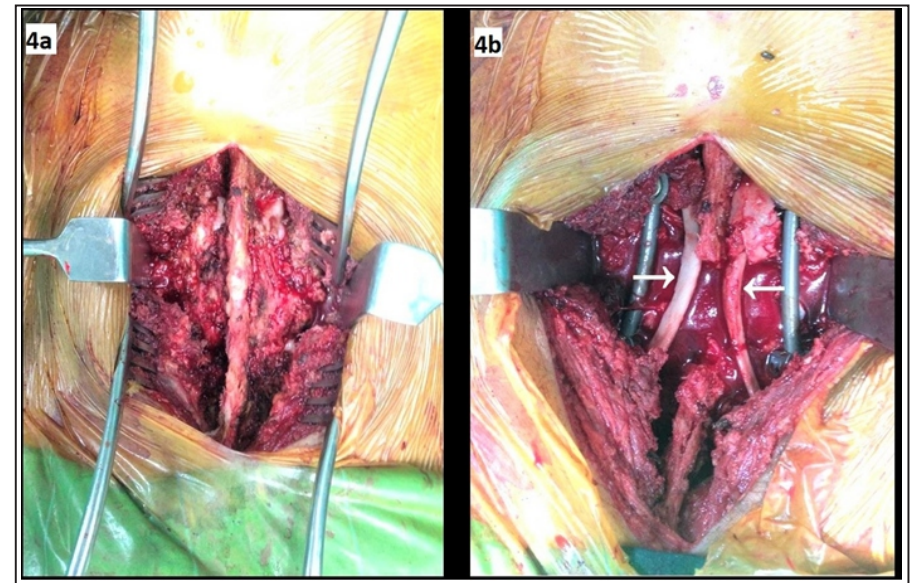

Figure 4: $[4 \mathrm{a}]$ showing posterior exposure of the lumbar vertebrae. [4b] demonstrates the insertion of autogenous rib graft (white arrows) after resection of the lesion to enhance the posterolateral fusion of the spine

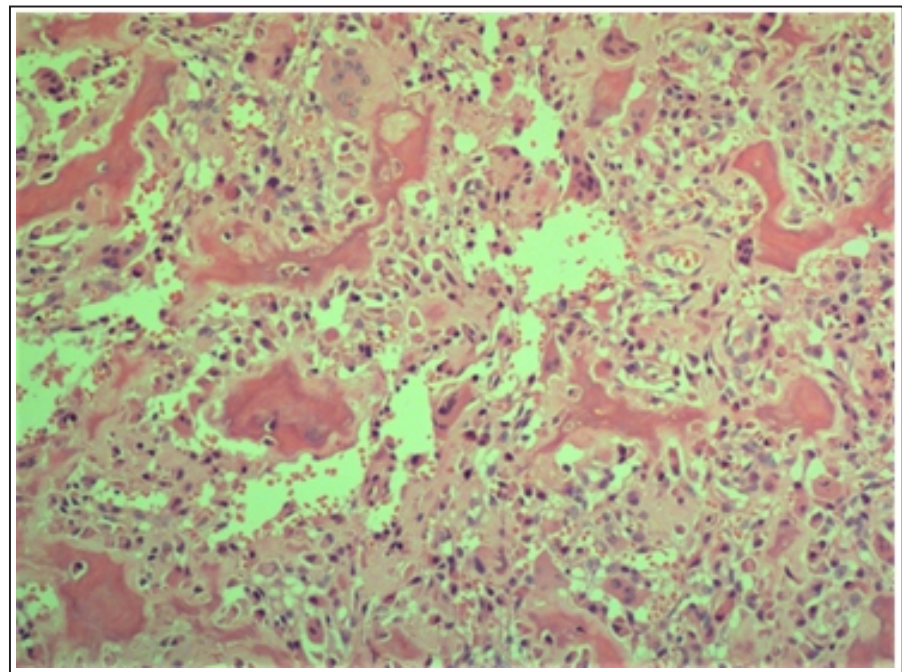

Figure 5: Haphazardly arranged bony trabeculae lined by single layer of osteoblasts are seen (H \& Ex 100) 


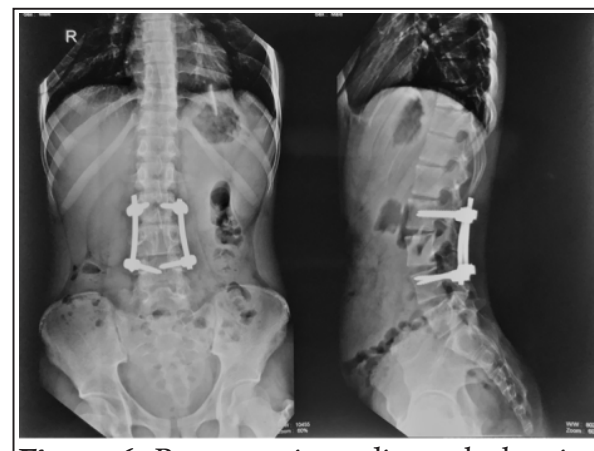

Figure 6: Postoperative radiograph showing short segment fixation from L2 to L4 with pedicle screws in situ with satisfactory incorporation of the rib grafts 2 years after surgery and no evidence of recurrence

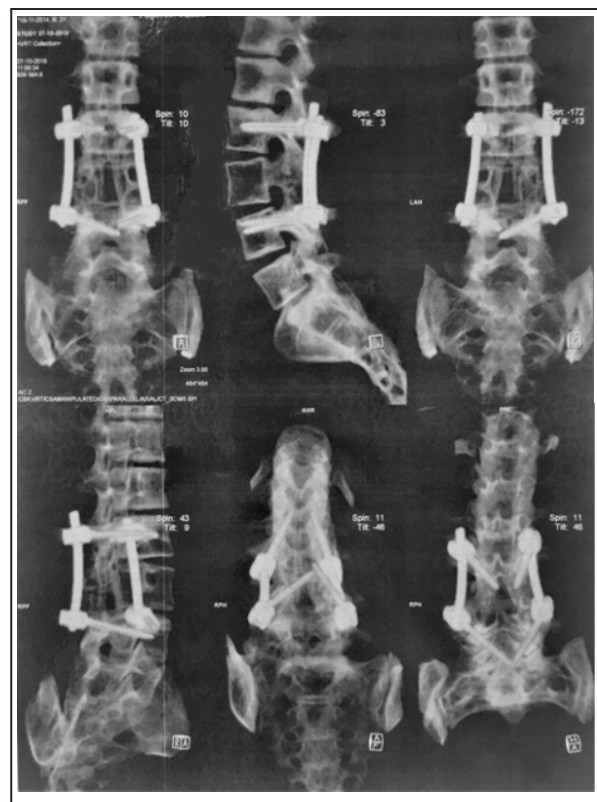

Figure 8: Postoperative CT scan demonstrating uptake of the rib graft and posterolateral fusion

opposite to the side of the lesion. Radiculopathy and neurological deficit with cauda equina syndrome can occur if the lesion impinges on the nerve roots or the spinal cord [3]. Thus, backache should not be presumed to be postural or inflammatory if long-standing and with red flags.

Investigations: Plain radiographs maybe less sensitive in picking up the lesion in early stages as lytic lesions

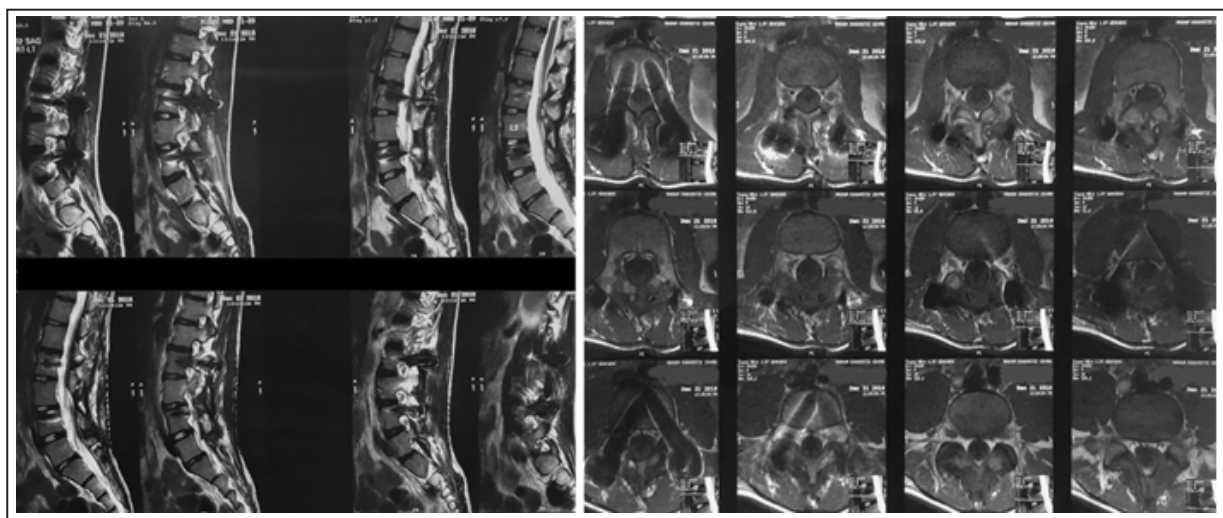

Figure 7: Sagittal and Axial sections of MRI 2 years after surgery demonstrating adequate decompression of the spinal cord, well positioned implants and no evidence of recurrence of the lesion

cannot be identified on radiographs unless there is approximately $50 \%$ bone destruction [4]. CT scan and MRI provide detailed information of the extent of the lesion, involvement of adjacent structures, distortion of local anatomy and intra-spinal extent of the lesion. A PET-CT scan detects involvement of other regions and allows staging.

Pathology: Osetoblastomas are known to be more aggressive tumours. Locally aggressive tumours can cause mass symptoms. Malignant transformation of osteoblastomas has also been reported [2].

Literature summary is shown in Table 1.

Treatment: Enneking staging has been used by many authors to guide the method of treatment [4,7]. Intra-lesional excision has been advised for Enneking stage 2 lesions and en-bloc resection for stage 3 [7]. Pre-operative arterial embolization has been shown to reduce intra-operative blood loss [8]. Surgical resection is the conventional treatment of choice for spinal osteoblastomas after meticulous surgical planning. Intraoperative use of navgation provides accurate localisation facilitating complete removal [9]. In this case interbody fusion was avoided as it would violate compartments. Stabilisation is warranted if excision of intervertebral joints or facets is done [5].

Minimally invasive options like CTguided radiofrequency ablation and image guided cryoablation may avoid need for fusion. Recently fully endoscopic resection has been described for spinal osteoblastoma. Use of denosumab preoperatively has been reported to regress tumour, ossify and facilitate resection [10].

To conclude, Autogenous rib graft can be used as a structural graft for posterolateral fusion after osteoblastoma excision with potential instability.

\section{Clinical relevance}

Back pain in adolescents should not be considered as postural or inflammatory especially when associated with red flags. The patient should undergo appropriate investigations to reach a diagnosis. Autogenous rib can be reliably used as a structural graft for posterolateral fusion.

Declaration of patient consent: The authors certify that they have obtained all appropriate patient consent forms. In the form, the patient has given his consent for his images and other clinical information to be reported in the Journal. The patient understands that his name and initials will not be published, and due efforts will be made to conceal his identity, but anonymity cannot be guaranteed.

Conflict of Interest: NIL; Source of Support: NIL 


\begin{tabular}{|c|c|c|c|c|c|c|c|c|c|c|c|c|c|}
\hline NAME & $\begin{array}{l}\text { AUTHORI } \\
\text { JOURNALI } \\
\text { YEAR }\end{array}$ & SAMPLE & SEX & $\begin{array}{c}\text { MEAN AGE } \\
(y \mathrm{r})\end{array}$ & LEVEL & $\begin{array}{l}\text { INVOLVED AREAS } \\
\text { OF THE VERTEBRA }\end{array}$ & SYMPTOMS & $\begin{array}{l}\text { ADJUNCTIVE } \\
\text { THERAPY }\end{array}$ & TECHNIQUE & BIOPSY & IMPLANTS & COMPLICATIONS & CONCLUSION \\
\hline $\begin{array}{l}\text { Osteoblastoma: A } 30 \text { year study } \\
\text { of } 99 \text { cases }\end{array}$ & $\begin{array}{l}\text { Micah Berry et al/ } \\
\text { Journal of Surgical } \\
\text { Oncology } / 2008\end{array}$ & 99 & $69, \mathrm{M}: 30, \mathrm{~F}$ & 24 & $\begin{array}{l}28 \text { in the } \\
\text { vertebra, rest in } \\
\text { the extremities }\end{array}$ & $\mathrm{NA}$ & $\mathrm{NA}$ & $\mathrm{NA}$ & $\begin{array}{l}\text { Curretage and } \\
\text { en-bloc } \\
\text { resection, } \\
\text { auto/allograft }\end{array}$ & $\mathrm{NA}$ & $\mathrm{NA}$ & Recurrence & $\begin{array}{l}\text { OBL frequently affects the long } \\
\text { bones and the spine. Recurrence } \\
\text { rates following curretage is relatively } \\
\text { high and can be minimised by } \\
\text { resection in selected cases }\end{array}$ \\
\hline $\begin{array}{l}\text { Management of osteoblastoma } \\
\text { and osteoid osteoma of the } \\
\text { spine in childhood }\end{array}$ & $\begin{array}{l}\text { Sasha Burn et al/ } \\
\text { Journal of } \\
\text { Neurosurgery: } \\
\text { Pediatrics/2009 }\end{array}$ & 33 & $20, \mathrm{M}: 12, \mathrm{~F}$ & $\begin{array}{c}\text { 13: OO, 12: } \\
\text { OBL }\end{array}$ & $\begin{array}{c}11 \mathrm{C}, 3 \mathrm{~T}, 15 \mathrm{~L}, 1 \\
\quad \text { Clivus }\end{array}$ & $\begin{array}{l}\text { Body and posterior } \\
\text { elements }\end{array}$ & $\begin{array}{l}\text { Pain, } \\
\text { radiculopathy, } \\
\text { stiffness, } \\
\text { scoliosis, } \\
\text { absent reflexes, }\end{array}$ & $\mathrm{NA}$ & $\begin{array}{l}\text { Subtotal or total } \\
\text { resection }\end{array}$ & $\mathrm{NA}$ & $\mathrm{NA}$ & $\begin{array}{l}\text { Paralytic ileus in 1, surgical } \\
\text { site infection in 3, }\end{array}$ & $\begin{array}{l}\text { Spinal } \mathrm{OO} \text { and } \mathrm{OBL} \text { can be a } \\
\text { challenging management problem in } \\
\text { pediatric patients. If conservative } \\
\text { therapy fails, surgery using modern } \\
\text { intra-operative imaging and spinal } \\
\text { instrumentation can provide } \\
\text { symptom relief and tumour control }\end{array}$ \\
\hline $\begin{array}{l}\text { Staging and treatment of } \\
\text { osteoblastoma in a mobile spine: } \\
\text { a review of } 51 \text { cases }\end{array}$ & $\begin{array}{l}\text { Stefano Boriani et al/ } \\
\text { Eur Spine } \\
\text { Journal/2010 }\end{array}$ & 51 & $34, \mathrm{M}: 17, \mathrm{~F}$ & 24.1 & $11 \mathrm{C}, 17 \mathrm{~T}, 23 \mathrm{~L}$ & $\mathrm{NA}$ & $\begin{array}{l}\text { Pain, scoliosis } \\
\text { in } 2\end{array}$ & $\begin{array}{l}\text { Pre-operative } \\
\text { embolisation, } \\
\text { Postoperative } \\
\text { radiotherapy }\end{array}$ & $\begin{array}{l}\text { Intra-lesional or } \\
\text { en-bloc } \\
\text { excision }\end{array}$ & $\mathrm{NA}$ & $\mathrm{NA}$ & $\begin{array}{l}\text { Death, progressive kyphosis } \\
\text { in 2, local recurrence and } \\
\text { implant failure, infection, } \\
\text { screw breakage }\end{array}$ & $\begin{array}{l}\text { Intra-lesional excision is effective in } \\
\text { Enneking stage } 2 \text { and en-bloc } \\
\text { resection in stage } 3\end{array}$ \\
\hline $\begin{array}{l}\text { Osteoblastoma of the sacrum: } \\
\text { report of } 18 \text { cases and review of } \\
\text { literature }\end{array}$ & $\begin{array}{l}\text { Pietro Ruggicri et } \\
\text { al/Spine/2014 }\end{array}$ & 18 & $16, \mathrm{M}: 2, \mathrm{~F}$ & 8.4 & L5.S4 & Anterior and posterior & $\begin{array}{l}\text { Low bak pain } \\
\text { and } \\
\text { radiculopathy, } \\
\text { neurodeficit }\end{array}$ & $\begin{array}{l}\text { Radiotherapy in } \\
1 \text {, phenol in } 7, \\
\text { and cryothcrapy } \\
\text { in } 1\end{array}$ & $\begin{array}{l}\text { Curettage, intra- } \\
\quad \text { lesional } \\
\text { excision, wide } \\
\text { resection }\end{array}$ & $\begin{array}{l}\text { Needle or open } \\
\text { biopsy or } \\
\text { intraoperative } \\
\text { frozen section }\end{array}$ & $\mathrm{NA}$ & $\begin{array}{l}\text { Massive blecding, wound } \\
\text { dehiscence, infection } \\
\text { requiring } 2 \text { surgical } \\
\text { procedures and external } \\
\text { radiotherapy }\end{array}$ & $\begin{array}{l}\text { Sacral ostceblastomas are rare, } \\
\text { difficult to diagnose and } \\
\text { complicated treatment choices, } \\
\text { intralesional ressection was } \\
\text { successful, local adjuxants did not } \\
\text { reduce recurrence. Preoperative } \\
\text { embolisation is recommended, }\end{array}$ \\
\hline $\begin{array}{l}\text { Surgical resection of osteoid } \\
\text { osteoma and osteoblastoma of } \\
\text { the spine }\end{array}$ & $\begin{array}{l}\text { Muayad Kadhim et al/ } \\
\text { Journal of Pediatric } \\
\text { Orthopedics B/2016 }\end{array}$ & 17 & $6, \mathrm{M}: 4, \mathrm{~F}$ & 11.5 & $\begin{array}{l}\text { 6C, 1T, 3L: } O O \\
1 \mathrm{C}, 2 \mathrm{~T}, 2 \mathrm{~L}: \\
\quad \text { OBL }\end{array}$ & $\begin{array}{l}\text { Only posterior elements } \\
\text { in osteoid osteoma, } \\
\text { posterior elements and }\end{array}$ & $\begin{array}{l}\text { Pain, stiffness, } \\
\text { radiculopathy, } \\
\text { scoliosis }\end{array}$ & $\mathrm{NA}$ & $\begin{array}{l}\text { Intralesional } \\
\text { excision, enbloc } \\
\text { excision }\end{array}$ & $\mathrm{NA}$ & $\begin{array}{l}\text { None, cable wire } \\
\text {, halo }\end{array}$ & $\begin{array}{l}\text { Persistent pain in } 1, \\
\text { recurrence in } 2\end{array}$ & $\begin{array}{l}\text { O-arm provided easy and accurate } \\
\text { localisation, and verification of } \\
\text { complete excision of tumour }\end{array}$ \\
\hline $\begin{array}{l}\text { Surgical management of } \\
\text { osteoblastoma of the spine: case } \\
\text { series and review of literature }\end{array}$ & $\begin{array}{l}\text { Benjamin Elder et al/ } \\
\text { Turkish } \\
\text { Neurosurgery/ } 2016\end{array}$ & 5 & $4, \mathrm{M}: 1, \mathrm{~F}$ & 28.4 & $3 \mathrm{C}, 1 \mathrm{~L}, 1 \mathrm{~S}$ & $\begin{array}{l}\text { Posterior elements of } \\
\text { cervical spine }\end{array}$ & $\begin{array}{c}\text { Pain, } \\
\text { neurodeficit }\end{array}$ & $\begin{array}{c}\text { Preoperative } \\
\text { embolisation in } \\
1\end{array}$ & $\begin{array}{l}\text { Intra-lesional } \\
\text { and en-bloc } \\
\text { excision }\end{array}$ & $\begin{array}{l}\text { CT guided } \\
\text { biopsy }\end{array}$ & $\begin{array}{l}\text { Pedicle screws, } \\
\text { Allograft, }\end{array}$ & Recurrence & $\begin{array}{l}\text { Aggressive surgical resection can } \\
\text { minimise risk of recurrence } \\
\text { although it may still occur after en- } \\
\text { bloc resection. Removal of } \\
\text { structural clements surgically makes } \\
\text { fusion often ncecessary. OO can } \\
\text { progress to OBL in the spine } \\
\text { despite previous resection. }\end{array}$ \\
\hline $\begin{array}{l}\text { CT-guided radiofrequency } \\
\text { ablation of spinal osteoblastoma: } \\
\text { treatment and long-term follow } \\
\text { up }\end{array}$ & $\begin{array}{l}\text { Francesco Arrigoni et } \\
\text { al/ Interrnational } \\
\text { Journal of } \\
\text { Hyperthermia/ } 2018\end{array}$ & 11 & 7,M: 4,F & 26 & $5 \mathrm{~T}, 4 \mathrm{~L}, 2 \mathrm{~S}$ & $\mathrm{NA}$ & Pain & $\mathrm{NA}$ & $\begin{array}{l}\mathrm{CT} \text { guided } \\
\text { radiofrequency } \\
\text { ablation }\end{array}$ & CT guided & $\mathrm{NA}$ & $\mathrm{NA}$ & $\begin{array}{l}\text { CT-guided radiofrequency ablation } \\
\text { is safe and effective for spinal OBL } \\
\text { with the advantage of being } \\
\text { minimally invasive }\end{array}$ \\
\hline $\begin{array}{l}\text { Percutaneous image guided } \\
\text { cryoablation of osteoblastoma }\end{array}$ & $\begin{array}{c}\text { Roberto Cazzato et al/ } \\
\text { Amereican Journal of } \\
\text { Radiology/ } 2019\end{array}$ & 10 & $7 \mathrm{M} ; 3 \mathrm{~F}$ & 21 (median) & $3 \mathrm{C}, 1 \mathrm{~T}, 1 \mathrm{~L}, 2 \mathrm{~S}$ & $\mathrm{NA}$ & Pain & $\begin{array}{l}\text { Pre-operative } \\
\text { embolisation in } \\
2 \text { cases }\end{array}$ & Cryoablation & In 7 patients & $\mathrm{NA}$ & $\begin{array}{l}\text { Permanent sensory deficit } \\
\text { in the arm, transient horners } \\
\text { syndrome, }\end{array}$ & $\begin{array}{l}\text { Percutancous image guided } \\
\text { cryoablation represents an effective } \\
\text { option for patients affected by } \\
\text { painful ostceblastomas. II can be } \\
\text { safely performed with } \\
\text { comprehensive protective measures }\end{array}$ \\
\hline $\begin{array}{l}\text { Can osteoblastoma evolve to } \\
\text { malignancy? A challenge in the } \\
\text { decision-making process of a } \\
\text { benign spine tumour }\end{array}$ & $\begin{array}{l}\text { Addisu Mesfin et al/ } \\
\text { World Neurosurgery/ } \\
2019\end{array}$ & 2 & M & 25,34 & $\mathrm{~L} .5, \mathrm{~T} 10$ & $\begin{array}{l}\text { Body, lamina and } \\
\text { pedicles }\end{array}$ & Pain, weakness & $\begin{array}{l}\text { Post-operative } \\
\text { radiotherapy }\end{array}$ & $\begin{array}{l}\text { Radiofrequency } \\
\text { ablation, } \\
\text { intralesional } \\
\text { excision, enbloc } \\
\text { resection }\end{array}$ & $\begin{array}{l}\text { CT guided } \\
\text { biopsy }\end{array}$ & $\begin{array}{l}\text { Pedicle screws, } \\
\text { cage }\end{array}$ & Recurrence and death & $\begin{array}{l}\text { Conversion of OBL to osteosarcoma } \\
\text { stresses upon performance of } \\
\text { appropriate enneking staging for } \\
\text { benign aggressive tumours as well as } \\
\text { always performing a biopsy } \\
\text { particularly at recurrencecif imaging } \\
\text { is not pathognomonic for a benign } \\
\text { primary tumour }\end{array}$ \\
\hline
\end{tabular}

\section{References}

1. Healey JH, Ghelman B. Osteoid osteoma and osteoblastoma. Current concepts and recent advances. Clin Orthop Relat Res. 1986 Mar;(204):76-85.

2. Kan P, Schmidt MH. Osteoid osteoma and osteoblastoma of the spine. Neurosurg Clin NAm. 2008 Jan;19(1):65-70.

3. Chi JH, Bydon A, Hsieh P, Witham T, Wolinsky JP, Gokaslan ZL. Epidemiology and demographics for primary vertebral tumors. Neurosurg Clin NAm. 2008 Jan;19(1):1-4.

4. Galgano MA, Goulart CR, Iwenofu H, Chin LS, Lavelle W, Mendel E. Osteoblastomas of the spine: a comprehensive review. Neurosurg Focus. 2016Aug;41(2):E4

5. Elder BD, Goodwin CR, Kosztowski TA, Lo SF, Bydon A, Wolinsky JP, Jallo GI, Gokaslan ZL, Witham TF, Sciubba DM. Surgical Management of Osteoblastoma of the Spine: Case Series and Review of the Literature. Turk Neurosurg. 2016;26(4):601-7.

6. Harrop JS, Schmidt MH, Boriani S, Shaffrey Cl. Aggressive "benign" primary spine neoplasms: osteoblastoma, aneurysmal bone cyst, and giant cell tumor. Spine (Phila $\mathrm{Pa}$ 1976). 2009 Oct 15;34(22 Suppl):S39-47.

7. Boriani S, Amendola L, Bandiera S, Simoes CE, Alberghini M, Di Fiore M, Gasbarrini A. Staging and treatment of osteoblastoma in the mobile spine: a review of 51 cases. Eur Spine J. 2012 Oct;21(10):2003-10.

8. Ruggieri $\mathrm{P}$, Huch $\mathrm{K}$, Mavrogenis AF, Merlino B, Angelini A. Osteoblastoma of the sacrum: report of 18 cases and analysis of the literature. Spine (Phila Pa 1976). 2014 Jan 15;39(2):E97E103.

9. Kadhim M, Binitie O, O'Toole P, Grigoriou E, De Mattos CB, Dormans JP. Surgical resection of osteoid osteoma and osteoblastoma of the spine. J Pediatr Orthop B. 2017 Jul;26(4):362-369.

10. Reynolds JJ, Rothenfluh DA, Athanasou N, Wilson S, Kieser DC. Neoadjuvant denosumab for the treatment of a sacral osteoblastoma. Eur Spine J. 2018 Jul;27(Suppl 3):446-452.

\section{Conflict of Interest: NIL}

Source of Support: NIL

\section{How to Cite this Article}

Sagade BS, Rokade SN, Dhawale AA, Nene AM. Osteoblastoma of the lumbar spine in an adolescent: A case report and review of literature. Journal of Clinical Orthopaedics July-Dec 2021;6(2):45-48. 